\title{
Drug Flooding of Northeast China \\ during the Governing of Japanese and the \\ Government of Puppet Regime of Manchuria
}

\author{
Li Sha, Xuejiao Zhang \& Zhan Zhang \\ Social Science Department of Shenyang University \\ No 21, Wanghua southern street, Dadong district, Shenyang 110044, Liaoning, China \\ E-mail: syhgs12@163.com
}

\begin{abstract}
After the September 18 Incident, in order to cater to the invading war, Japanese invaders carried out the Opium Policy of Poisoning Chinese in the occupation zone, which aimed at providing economic aid for Japan's invading war and disintegrating Chinese resistant will. The three periods of implementing the policy were: period of monopolization, period of cutting off the supply and period of supporting the war through trafficking. Drug flooding had a disastrous influence on the northeasterners of China.
\end{abstract}

Keywords: Opium policy of poisoning people, Northeast China, Disastrous influence

From the September 18 Incident in 1931 to the end of the war of resistance against Japan in 1945, in order to cater to the invading war, Japanese government and army enforced a very sinister and diabolic policy during the 14 years ---the opium policy of poisoning people. The enforcement of the policy brought dreadful disasters to Chinese.

Northeast China was the first region falling to Japan's occupation. It was also the center and base where Japanese army manufactured and trafficked drugs. Northeasterners witnessed the whole process of the enforcement of the opium policy and suffered badly from it. Even now, when we review the piece of the history, it is still startling.

\section{The whole process of Japanese invaders' enactment and enforcement of the opium policy of poisoning people}

It's been so long since Japanese invaders had trafficking in China. As early as the end of 19th century, when westerners began to smuggle drugs in China, they played an active role in the sinful trafficking. With the aid of Dalian customs they controlled, some Japanese drug dealers imported large quantities of opium from Europe and America. After Russo-Japanese war, Japan set up Kwantung Supervisory Government in Dalian. In 1906 Kwantung Supervisory Government set up Kwantung Opium General Bureau and established its branches in other areas, creating two trafficking webs of official and illicit sale. They began to deal in drugs openly and reaped a lot of benefits from it. From then on, many dens of making and selling drugs appeared, and different types of dens increased rapidly. Drugs began to overflow in Northeastern.

After the September 18 Incident, Japanese occupied the whole Northeast China quickly. In the second year, Japanese government propped up the puppet government of Manchurian in Northeast of China. They plotted and enforced a new opium policy actively to support the invading war. During the war of aggression against China, the development of the opium policy went through three major periods: period of monopolization, period of cutting off the supply and period of supporting the war through trafficking.

\subsection{The formation of opium monopolization system after the September 18 Incident}

Opium was a special weapon, and Japanese invaders knew clearly the opium would play an important role in the invading war. In Feb.1932, Kwantung Army set out to plot a new policy of opium. Koiso Kuniaki, the chief of staff of Kwantung Army, Okamura Yasuji, vice chief of staff of Kwantung Army, Hoshino Naojyo, dean of general affairs of Financial Department and other officers schemed together, establishing the fundamental guideline of the new opium 
policy in Manchukuo . First, they would have a monopoly on opium in Manchukuo, aiming at increasing the financial income to strengthen the ruling in the colony and expand the invading war. Keiichi Naniwa, the commissioner of Kobe Inland Revenue was recruited to China, in charge of opium monopolization. Second, they planned to plant a large amount of poppies, manufacture opium and narcotics and carry trafficking everywhere in Manchukuo. Moreover, with Manchukuo as the foothold, Japanese would have a lot of dealings with other countries in the world. Taking the advantage of its nominal independence, they could impute the accusation to the puppet government.

In the late February, Keiichi Naniwa, arrived in Northeast China and took office. In order to work out the shortage of opium, he went to Tianjin secretly, purchasing opium 500,000 liang in North China, 200,000 liang from Japan and importing opium 2,000,000 liang from Persia, which summed up to 2,700,000 liang. The opium flowed into Northeast China quickly by the trafficking web under Japanese control. From then on, the action of opium policy launched at an alarming rate in Liaoning and the whole Northeast China.

In autumn 1932, Tokumi Koumai, the chief of office of general services claimed on the newspaper: "People of Manchukuo enjoy opium. To cater to people, the government will have a monopoly on opium. People in Manchukuo are allowed to get the permit of planting opium and smoking opium openly." As soon as the statement was issued, the puppet government announced some regulations related to opium monopolization.

On September 16, 1932, Japanese invaders published Temporary Opium Purchasing Law through the puppet government, set up a preparatory committee in charge of opium monopolization. In November 3 the Opium Monopolistic Bureau was set up, directly under the jurisdiction of the financial department. At the same time, many branches, led by the Opium Monopolistic Bureau directly, were also established in Mukden, Jilin, Chengde, Yingkou, Andong, Jinzhou and etc, in charge of the monopolistic dealings of opium. There were also 20 monopolistic branch offices and 80 retail outlets in counties and banners. The web of opium monopoly began to take shape.

On November 30, the Opium Law and the Implementation Regulations were promulgated by the puppet government. It was prescribed by the Opium Law that taking drugs was forbidden; drug addicts must be registered and the government would provide the permits to the drug addicts, who could smoke the opium paste the government sold in restricted quantity; government would allot the region and the area of planting the poppy; the manufacture, purchase, processing, storage and the marketing of the opium, as well as the manufacture and purchase of the instruments of smoking opium, were all under the control of the government. It seemed that the planting and the smoking were forbidden by the Opium Law elegantly. However, only the manufacture and the marketing of opium beyond the control of the government were forbidden. The Opium Law was in fact the ruling law and the official law of trafficking. According to the law, Japanese reaped all the benefits. The Opium Law established the legitimacy of the monopolistic system of opium. The puppet government of Manchurian transformed into a legitimate institution of opium monopoly and open trafficking.

From 1933, great quantities of poppy were planted in Northeast China under the supervision of the puppet government of Manchurian. Peasants were compelled to plant poppies and sold the poppies to the government at a very low price. The puppet government of Manchurian made the plan of poppy planting in October every year and distributed the plan to the related governors; the governors set the assignment for the related counties and banners. At the end of the year till February next year county-class governors would examine and agree the planting plan the planters had made. Planters were required to peg out the land to provide the information of planting, such as the name, the address of the planter and the area of planting etc. Unauthorized planters were forbidden to plant poppies and the poppies would be cut out if their planting behaviors were found. According to statistics, from 1933 to 1936, "the areas of opium planting had covered 14 of the 16 provinces the puppet government set out. The planting area was 177,750 acres, and the annual output of opium was 1,271 kilos. (Wang, Depu, 1946. p.57)

The puppet government of Manchurian regulated that the planters could only sell opium to the authorized purchasing companies. At that time, there were two purchasing companies established by Japanese in Mukden, Daitoukou and Daimankou. Daimankou purchased opium from the western region and_Daitoukou was responsible for the eastern purchasing affairs. In addition, the Opium Monopolistic Bureau also imported opium multimillion liang from Iran, India and Korea every year. Moreover, the Puppet government set up a big factory in Mukden to manufacture and process the opium of purchasing and importing, which aimed at producing the opium paste 6 million liang, narcotics 2000 kilos every year, and increasing production continuously every year.

Opium Monopolistic Bureau was responsible for the wholesale and retail of opium. The Financial Department appointed the wholesalers of every province and the governors of the provinces appointed the retailers. After retailers got opium, they began to do opium business, arranging the instruments of opium smoking, simmering opium into well-made opium paste to supply for the customers in the opium dens set up by the retailers everywhere. According to the official statistics, there were 2196 opium dens in Northeast China in 1937.

Under the Opium Policy of poisoning people in Manchukou, Japanese earned big profit within a couple of years. The high price of purchasing opium rose from 1.05 yuan per liang in 1933 to 1.30 yuan per liang in 1937. While, the price of 
selling the opium rose from 40 yuan per liang to 55 yuan per liang. The selling price of opium was 40 times higher than the purchasing price. The net gain of Japanese and the puppet government was 370,000 yuan in 1932. In 1937, the income of trafficking rose up to 1,264,000 yuan. Of the whole income of Manchukou, the income of trafficking "took up $6.2 \%$ in 1932 and $8.5 \%$ in 1937." (Li, Zuoquan, 1985, p.130)

In July 1937, Japanese ordered that the manufacturing, importing and selling of morphine and heroin were all under the control of the Monopolistic Bureau according to the Narcotic Law by the puppet government. Because the output of heroin increased continuously in the factories in Mukden, the supplies were not only for the local drug addicts, but also transported to Tianjin, Shanghai, and even smuggled to the west coast of the U.S., Canada and Europe under the safeguard of Kwantung Army.

During the five years of opium monopoly, the poppies were blooming everywhere in Manchukou. Edgar Snow, a famous correspondent of America, after visiting Manchukou, wrote in his report that "thousands of peasants began to plant poppies instead of soybeans because of the encouragement of Japanese. While traveling by train in Manchukou, I did not see crops in the field, what I often saw was only the poppies of thousands of hectare." (Li, Shujuan, 2005, p.198.)

\subsection{Falsity and duplicity of the Opium Policy of cutting off the supply during the years from 1938 to1941}

After the opium policy was put into effect in Northeast China, people suffered a lot and hated it deeply, and the policy was also condemned by the world opinion. In 1937, the 22nd meeting of Opium and Drug Committee of League of Nations was held in Geneva. Representatives of many countries revealed, condemned and criticized the infamy of Japanese trafficking in China. They requested strongly that Japanese government take effective measures at once to stop the illicit action of manufacturing and selling drugs in China.

Under the pressure of public opinion, in order to weasel out of the international denouncement, Japanese had to make a new plan. Meanwhile, due to the great benefit from trafficking, Japanese invaders didn't want to give up the trafficking and intended to ensure the huge financial income. Therefore, in 1938, Hoshino Naojyo, dean of general affairs, and Tadayuki Hrumi, chief comptroller, developed the policy of "cutting off the supply of opium during ten years" to deceive people.

The puppet government claimed that the policy of cutting off the supply of opium came into effect from 1938, that the government would gradually reduce the opium planting area every year, and that the poppy planting would be abolished in the 8th year and all the drug addicts would give up taking drugs in the 10th year. In order to fulfill the plan, Japanese and the puppet government of Manchuria set up the Opium Control Committee, hyping over ban on opium-smoking and claiming their innocence to cheat and mislead people. In December 1939, they set up the General Bureau of Ban-on-Smoking to deal with all the opium affairs instead of the Monopolistic Bureau. All the branch bureaus the retail sites in the towns, counties and banners were transformed into the departments of drug control. The puppet government took over those institutions directly and cancelled the profiteers from wholesaling and retailing to increase the income of the government. The puppet government cancelled the companies Daimankou and Daitoukou to strengthen the centralized management of planting, purchasing and selling of opium.

Japanese and the puppet government banned opium nominally. Actually, they tried to carry out the opium policy in the name of ban on opium. On the initial stage of ban, they intended to control all the drug addicts, obliging them to register for the permits, and people under 25 could not get it. People without the permits could not smoke. It seemed that all the drug addicts were restricted. In fact, everyone could get the permit as long as he had applied for it without any examination. Moreover, the drugs handed out by the management institutions were the well-done opium paste, very cheap, convenient and in high quality. As a result, people rushed to register. In this way, more and more people fell into the opium web.

The second period of the opium policy of killing people came when many people became addicted to the drugs. Although opium was poisonous, people who smoked the raw opium wouldn't die at once but had poor health, shortened life span and the diminished fertility. In the stage of cutting off the supply, Japanese schemed a new guilty plan again. The raw opium was sent to Nanling Science College in Xinjing, which was actually a factory where Japanese made morphine, narcotics, heroin and drugs. Japanese took out the essence of opium as the army's narcotics, and then mixed the dregs of opium with the stimulating sulfur, making the opium bubbles for Chinese. Smoking this kind of drugs, people were liable to become addicted. The more people smoked, the more poison people took. And it was very hard to give up. People would get an incurable disease after taking this kind of drugs within one year and died soon. It was the best way to kill Chinese and extinguish the Chinese nation from Japanese point of view.

Japanese was so evil-minded that they pretended to be a philanthropist. In order to deceive people, Japanese and the puppet government set up the Kangsheng clinics (a kind of clinic for the deep addicts) for the numerous drug addicts, and made the regulation that the drug addicts could be treated in the Kangsheng clinics. The police bureau decided if the drug addicts could be treated in the clinics according to their poisoning degree. But it was only deception to set up the 
kangsheng clinics. Firstly, there were only a few Kangsheng clinics while too many drug addicts needed to be treated. For instance, in Longhua county, the clinic was a temporary institution with the capacity of only 70 people. Of the population of 22,000,000 of the county, there were nearly 1,000,000 drug addicts. It was impossible to treat all the drug addicts." (He, Junzhou, 1989, p.175.) In 1941, there were 12,370 drug addicts in 189 Kangsheng clinics in Northeast China. The treatment the addicts could get was little more than a drop in the ocean. Secondly, the condition of Kangsheng clinics was very poor and there were not formal doctors in those clinics. To make a profit, officials in those clinics sold drugs at a high price to the drug addicts. Nobody could give up smoking opium there. Actually, the Kangsheng clinic was another form of trafficking site and opium den to blackmail the drug addicts.

Although Japanese and the puppet government claimed to forbid opium, the production of opium never stopped and the output had been growing continuously. In spring every year, Japanese and the puppet government organized the exploration teams which would go to the countryside and measure the area of planting opium. The amount of the opium every family planted must be in accordance with the planting assignment and the output of dried opium should correspond to the degree of land. When these teams reached the villages, they colluded with the local despotic landlords and rogues, bullying the poor peasants. The rich and influential families usually planted more than they reported to the government, leaving some surplus opium for themselves, while small families planted less than they reported. So in autumn the poor peasants of the small families could not finish the assignment. They had to go into the mountains, cultivating the waste land to plant the poppies. Due to the serious corruption, the land that the poor peasants were obliged to cultivate enlarged continuously, and the output of opium increased too. Meanwhile, more and more people became the victims of the opium.

In the harvest time, the working teams of the Japanese and the puppet government went to the countryside and gathered all the opium. They did not leave any surplus in the countryside, claiming they would protect the villagers in case that someone smoked the surplus opium. In this way, they collected all the opium, including the opium that poor peasants planted in the newly-cultivated land and rich families concealed. The peasants would be tortured or even killed if they did not fulfill the assignment and provide enough opium for the working teams. By this means, the working teams could not only complete the government's assignment but also keep the drug addicts from getting the surplus opium in the countryside, which forced them to buy the drugs and opium bubbles the government sold. As a result, many officials made piles of money by oppressing the poor, while exploited by Japanese and the officials of the puppet government, the poor planters became much poorer and even lost all their properties in the end.

\subsection{After the Pacific war, Japanese supported the war with the lunatic drug trafficking}

The opium policy that Japanese carried out in Manchukuo had two major functions: one was to earn the financial income to support the war, and another was to weaken the competitive spirit of Chinese and break their will of resistance, causing them to lose their national consciousness. So it was impossible for Japanese to give up the policy regardless of the international condemnation. In 1941 the Pacific War broke out. Being the base of the war, Manchukuo had to increase its production continuously. And opium, as special military supplies and the origin of financial income, became more important in the emergency period. The General Bureau under the name of ban on opium did business of the opium monopolization again. Places of quitting smoking turned into the open drug-smoking sites, nobody thinking about the register system. All the camouflage of ban on the opium thoroughly vanished, and the nature of the imperialism became apparent." (Central Archives, p. 815)

In 1942 and 1943, the Opium Meeting of Greater East Asia was held in Tokyo, Japan twice. An agreement was reached at the meeting that Manchukuo and Mengjiang became the bases of opium planting and were responsible for supplying the opium for the whole east Asia. Japanese government and the army responded to the plan actively, deciding to throw away the policy of cutting off the opium at once and increase the production of opium as soon as possible. The same year, they not only resumed the former area of opium planting in Manchukuo, but also expanded the planting area to the flat land. A large quantity of poppies were planted in the fertile land along the railway from Changtu county to Haicheng county. Land of 1000 hectare in three provinces of Mukden, Jilin and Siping were defined to plant the opium collectively. After 1944, in order to strengthen the management of the opium planting and selling and prevent the planting land from reducing, Japanese and the puppet government set up the group system, gathering the planters. Every head of the group was Japanese, in charge of the guidance and supervision and the opium was paid in the group. The peasants were compelled to plant opium and wide stretches of fertile land were utilized to plant the poppies. In order to increase the production of opium, Japanese and the puppet government ordered to utilize the best land to plant opium. The peasants put a great deal of money, labor and manure into the land, hoping to plant more opium instead of crops. Fertile land became desolate without being cultivated. The decrease of crops resulted in the shortage of grains, famines of years and the mismanagement in the farm sector and agricultural economy. The price of oil, coal and cloth rose fast in the rural area. People complained incessantly. The economic structure of agriculture in Northeast deformed.

With the expanding of opium production, the income Japanese and the Manchukuo government received from opium also increased continuously. The output was 12,000,000 liang in 1943 and 15,000,000 liang in 1944. Smuggling opium, 
Japanese and the puppet Manchukuo government reaped fabulous profits and got military supplies to support the invading war. At the end of October 1941, in order to pay off the loan of about 7 million German Mark, Japanese sold 7 ton of opium to Germany.

In January 1943, Japanese decided to set up the special financing department in Manchukuo Central Bank to support the decisive battle in the economic way and established Manchukuo Trading Co., Ltd. in which the puppet government invested 500 million for purchasing and exporting opium. The same year in Hong Kong, Japanese Kwantung Army exported 20,000 liang of opium in return for the raw material of the special steel, tungsten. In 1944, Showa Steel Factory was attacked in the air. Japanese had urgent dealings with Shanghai, buying locomotives and tools with a lot of opium and fur. In February 1945, having dealings with Japanese Navy in North China, the puppet government got war material with opium, steel and corn, etc. The puppet government yielded fat profits from trafficking. Every year after 1942 , they could get 10,000,000 yuan and even 30,000,000 yuan in 1944. The high opium income put heavy financial burden on Chinese, and made Japanese army more and more arrogant.

\section{Opium and drugs ruined people in Northeast China ruthlessly both in body and mind}

\subsection{Opium spread in the populace at large.}

Thousands of Chinese in old China suffered from the opium policy of killing people. In Northeast, many people from military commanders to businessmen and peasants sank into the drug web and became addicted. In 1933, when the policy was put into effect, the Opium Monopolistic Bureau printed a lot of opium permits and handed out to every police station. People, young and old, addicted or not, could get the permit with the valid period of half a year and take drugs at home or at the opium den. There were two kinds of opium den: one was for the rich in cities, called luxurious opium house; another was for the poor in the rural area, called simple opium den. Because opium dens existed everywhere, it was very convenient to take drugs, and the number of drug addicts increased very quickly. "Since the opium policy of killing people was carried out, at least 2,544,000 people had became addicted." (Central Archives, p. 823)

\subsection{Drugs seriously damaged the physical and mental health of people in Northeast}

Under the opium policy of killing people, most of 3,000,000 northeasterners became drug addicts. Many young people were bags of bones, vulnerable and in low spirits, totally losing the national consciousness. Many drug addicts who were once good laborers lost their working ability and ruined their own lives and families in the end. There was a clever saying in old society: people who smoke opium had "three quickness", poor quickly, dead quickly, removed quickly (The dead were very thin.). According to the statistics of Harbin Public Health Bureau, "1993 nameless corpses were found in the alleys and streets of the city from January to July in 1937. According to the data provided by Mukden police station, 67 people died of opium in November 1937." (Wang, Depu, 1946. p. 57) In the whole Manchukuo, " 179,000 addicts died of opium during the 12 years, from the beginning of the opium policy to the end of Manchukuo." (Central Archives, p. 823).The drugs would shorten the life span of people and drastically reduce fertility, even their next generation could get the toxin because of heritage and become deformed. Both the quality and quantity of the population in Northeast declined rapidly with bad influence.

\subsection{Fashion of taking drugs corrupted social morality.}

Before Japanese occupation, Northeast was ruled by some warlords, and the policy of ban on opium-smoking and the opium trade was strictly implemented. So only the few rich could get access to the drugs. During the period of Manchukuo, everyone was allowed to take drugs and taking drugs became a kind of fashion. In some social occasions, drugs became a kind of necessity to serve the guests. The landowners, gentries and officials of upper class intended to show off their wealth by taking opium,

Opium dens turned into the recreation areas for taking drugs, drinking, gambling and chasing after women. More and more people assimilated easily and quickly in the bad environment. In the vast rural area, deceived and seduced by the propaganda of Manchurian government, the peasants once believed that taking drugs could cure the illness and planting opium could make them richer. However, after becoming addicted, they lost their family properties in a short period of time, suffering from both poverty and sickness. To satisfy their craving for opium, some peasants had to sell their children, or even compelled their wives to engage in prostitution. Some desperate ones took risks committing snatching, murder and arson, and became robbers, or even bandits.

In a word, the opium policy enforced by Japan and the Puppet Government in the Northeast China was a Japanese national policy which served the invading war. It brought about a great disaster to people in Northeast China. Although Japanese invaders fulfilled their evil purpose, Japan, with the image of a drug dealer, has been impaled at the historical stake of disgrace and leaves such a bad name which will long be remembered in the world, the reputation losses are unmeasurable and will never be compensated. 


\section{References}

Central Archives etc. Archives Selects of Japanese Imperialists Invading China: Economic Plunder in Northeast. p. 815 and 823 (Chapter 14).

He, Junzhou. (1989). the Lowdown of Drug Ban in Longhua Country during the Period of Manchukuo. Cultural and Historical Data of Jinzhou. Liaoning People's Press. Shenyang .1989. p.175.

Li, Shujuan. (2005). Northeast Countryside under the Governing of Japanese and Manchukuo. Modern China Press. Beijing. 2005. p.198.

Li, Zuoquan. (1985). The Opium Policy of Manchukuo. 1985 Yearbook of the Exhibition Centre of the puppet palace. p.130.

Wang, Depu. (1946). "Japanese Crime of Poisoning Chinese by Drugs in the Occupied Zone" Republican Archives.V.1 1994.56--60 